\title{
Understanding the usage, Modifications, Limitations and Criticisms of Technology Acceptance Model (TAM)
}

William Ratjeana Malatji', Rene Van Eck, Tranos Zuva

School of Applied and Computer Science, Department of ICT, Vaal University of Technology, Vanderbijlpark, 1911, South Africa

\begin{tabular}{l} 
A R T I C L EI N F O \\
\hline Article history: \\
Received: 23 July, 2020 \\
Accepted: 14 August, 2020 \\
Online: 08 November, 2020 \\
\hline Keywords: \\
TAM \\
User acceptance \\
Perceived usefulness \\
Perceived ease of use \\
Behavioural intentions \\
Criticisms \\
Limitations
\end{tabular}

\section{Introduction}

Academics and practitioners have developed an interest in recognizing the factors that affect users' acceptance or denial of modern innovation [1]-[5]. Providing an answer to this question might assist them to improve techniques for assessing, predicting, and designing the feedback of customers to the new innovations [6]. Technology Acceptance Model (TAM) and frameworks were implemented in an expansive range of domains to comprehend and foretell users' behaviour for instance fasting, education, elections, etc. [7].

Numerous researchers in the discipline of technology acceptance, improved models, and frameworks to evaluate the utilization of modern innovations. These models introduced

\footnotetext{
* Corresponding Author: William Ratjeana Malatji, villywr@gmail.com

factors that contribute towards user acceptance [4]. TAM has been repeatedly studied and being extended to the two important upgrades named the TAM2 [8] and the Unified Theory of Acceptance and Use of Technology (UTAUT) [9]. TAM3 which includes the effects of use and perceived risk on system utilization in the circumstance of e-commerce was proposed by [10]. Numerous studies have utilized these traditional systems to carry out their studies and the remaining joint past models [11]. Great innovation and implementation may be planned and improved but if human beings do not partake and utilize it, the project is unsuccessful, therefore, user acceptance is not a deniable key of any continuous application and improvement of any innovation and implementation [4].

This paper aims to determine and understand usage and modifications, limitations, and criticisms of Technology 
Acceptance Model (TAM) for IT acceptance. User acceptance and confidence are of great importance for further improvement and to the successful application of any new innovation. Due to above-mentioned reason, it is necessary to determine and understand the usage and modifications that were made to Technology Acceptance Model (TAM). Therefore this paper is arranged as follows; Background, TAM criticisms and limitations, and conclusion.

\section{Background}

Growing the interest of customers' response toward Information Technology (IT) increased the significance of theories and models that foretell and describe information technology acceptance and utilization [4]. Researchers accepted and used theories and models such as Theory of Reasoned Action (TRA), Social Cognitive theory (SCT), Technology Acceptance Model (TAM), Theory of Interpersonal Behaviour (TIB) etc. to evaluate the usage of new innovations [4]. Several studies utilized these original frameworks to carry out their researches; however, in this paper TAM is the main focus.

\subsection{Technology Acceptance Model}

Technology Acceptance Model is one of the greatest leading extensions of [12]'s Theory of Reasoned Action (TRA) in the related works. In the 1980 s TAM was created, given that employees were not utilizing Information Technologies made accessible to them [13]. Its founders highlighted that the way to multiplying the use was to initially multiply acceptance of information technology, which might be evaluated by questioning persons regarding their future intentions to utilize information technology [14]. Recognizing elements that formed a person's intentions might enable organisations to modify those factors so that they can improve acceptance and therefore multiply IT utilization [14].

An earlier TAM study found that three variables were required to describe, foretell and manage acceptance [15]. To reach this model, the founders adopted TRA, a universal socialpsychological or behavioural theory which was confirmed suitable for comprehending different behaviours for example; exercise, condom use and voting [15]. As it was usual to adapt such theory to new circumstances, an introductory study was carried out to discover what could be the proper variables to add on comprehending IT utilization behaviour [12]. The variables chosen and created the first model of TAM are described in Table 1.

According to [16] TAM substitutes numerous attitude measures of the TRA with multiple technology acceptance measures namely, ease of use and usefulness. Moreover, TAM and TRA, which both contain powerful behavioural components, presume that when an individual develops a willingness to take action, that individual will act freely without any limitation. It is necessary to expand TAM to incorporate variables that are responsible for changing methods and that this can be attained by adopting the innovation Model into TAM [17].

\subsection{Usage and Modifications of TAM}

Numerous researchers have used TAM to carry out their studies. TAM was used by [18] to investigate the learning effectiveness of utilizing IT as a learning podium. The findings of the study highlighted that PEOU, PU, and perceived playfulness might all be utilized to efficiently foretell the learning behavioural intention of scholars (the variables are explained in detail in Table $1)$. The theory of planned behaviour and the expectationconfirmation model was used for two hundred and seven mobile information system users to investigate their behavioural intention to continue utilizing the system [19]. The findings of the study highlighted that consumer approval, PU, and perceived playfulness remained the main components for consumers to carry on utilizing the system.

TAM was used by [19] to examine Chinese clients' behavioural intention about instant messenger. The conclusion was reached that PU and perceived playfulness directly affect clients' attitudes. Using the theory of planned behaviour, it was found that social norm and perceived behavioural control might as well have a direct influence on BI. Moreover, [20] carried out a study on the utilization of emails and file processing software by one hundred and twenty workers in IBM Canada Laboratory. They discovered that workers' PU, PEOU, and software utilization were positively and significantly correlated.

TAM was used by [21] to study the behavioural intention (BI) of scholars in the higher institutions of learning and utilize a webbased application evaluation framework as an instrument to assess their specialised capability in e-book creation. The study discovered that participants' computer self-efficacy positively influence PEOU and PU. Participants' PU and PEOU also had considerable and direct influences on their intention to utilize the framework. Thus, when a person possesses greater computer selfefficacy with a greater point of view of the usefulness and ease of use of the web-based valuation framework, that individual will be more willing to utilize the framework.

TAM theory went through numerous changes. For example, an upgraded named TAM2 erased attitude (ATT) variable from the model, which initially arbitrated some of the effects of PU and PEOU. TAM2 also included a variable meant to capture the social influence that forces end-users to positively assess and welcome information technology, named subjective norm (SN) [9]. The connection amongst variables which were hypothesised from the theory that proposes and motivates the combination of TAM and DIT are:

- Social influence negatively impacts complexity of understanding.

- Social influence positively impact triability.

Lately, an impressive attempt to merge the information technology acceptance writings brought about the UTAUT (defined in Table 2), a theory with clear similarity to TAM [9]. UTAUT includes PU into a performance expectancy construct, PEOU into effort expectancy and SN as social influence (the terms are defined and explained later in Table 1). Modern to UTAUT, but not to the information technology acceptance study generally is the modelling of easing circumstances as one determining factor of behavioural intention [22]. UTAUT is a modern but capable theory; Prior experiments of UTAUT described a magnificent 70 percent of the variance in behavioural intention and at most 50 percent in actual use [22]. It has been embraced by current studies in healthcare, this include: 
- The Modern Portfolio Theory (MPT): Independent of TAM, [23] designed the technology model and matching human being as part of national science foundation-funded dissertation research. The modern portfolio theory is fully explained in Scherer (2005)'s text.

- The Hedonic-Motivation System Adoption Model (HMSAM): TAM has been successful in describing multiple systems utilization (i.e. E-Learning, web portals, learning management system, etc.) $[24,25]$. Nevertheless, TAM is not preferably relevant to describe the adoption of completely inherent or hedonic frameworks (e.g. learning for pleasure, music, online games etc.). HMSAM was developed to better the understanding of the Hedonic-Motivation System Adoption Model [26].

- Extended TAM: Numerous studies suggested an expansion of original TAM by including variables that are external on it with an intention of investigating the outcomes of factors that are external on user attitude, actual use and behavioural intention of an innovation [24, 25]. This model became implemented in acceptance of health care innovations [27].

Technology Acceptance Model and its improved versions are not appropriate for all applications since they exclude main constructs such as perceived risk[28]. Therefore TAM has also turned out to be an accepted model that can be expanded and adjusted [28, 29].

The table below lists and defines the variables in TAM and related models since TAM theory has undergone numerous changes.

Table 1: TAM variables and related models

\begin{tabular}{|l|l|l|}
\hline \multicolumn{1}{|c|}{ Variable } & \multicolumn{1}{|c|}{ Definition } & $\begin{array}{l}\text { Models that } \\
\text { include the } \\
\text { variable }\end{array}$ \\
\hline $\begin{array}{l}\text { Behaviour } \\
\text { Use (BU). }\end{array}$ & $\begin{array}{l}\text { One particular behaviour of interest } \\
\text { made by persons with great } \\
\text { consideration to a certain } \\
\text { information system. }\end{array}$ & $\begin{array}{l}\text { TRA/TPB, } \\
\text { TAM, } \\
\text { TAM2, } \\
\text { UTAUT. }\end{array}$ \\
\hline $\begin{array}{l}\text { Behavioural } \\
\text { Intention (BI) }\end{array}$ & $\begin{array}{l}\text { A person's inspiration or intention to } \\
\text { apply an effort to carry out the } \\
\text { objective behaviour. }\end{array}$ & $\begin{array}{l}\text { TRA/TPB, } \\
\text { TAM2, } \\
\text { TAM, } \\
\text { UTAUT }\end{array}$ \\
\hline $\begin{array}{l}\text { Attitude } \\
\text { (ATT) }\end{array}$ & $\begin{array}{l}\text { A person's evaluative decision of the } \\
\text { objective behaviour on a certain } \\
\text { dimension. }\end{array}$ & $\begin{array}{l}\text { TAM, } \\
\text { TRA/TPB }\end{array}$ \\
\hline $\begin{array}{l}\text { Perceived } \\
\text { Ease of Use }\end{array}$ & $\begin{array}{l}\text { A being's point of view that utilizing } \\
\text { an IT framework will be effortless }\end{array}$ & $\begin{array}{l}\text { TAM, } \\
\text { TAM2 }\end{array}$ \\
\hline $\begin{array}{l}\text { Perceived } \\
\text { Usefulness } \\
\text { (PU) }\end{array}$ & $\begin{array}{l}\text { A being's point of view that utilizing } \\
\text { IT framework will improve job } \\
\text { performance }\end{array}$ & $\begin{array}{l}\text { TAM, } \\
\text { TAM2 }\end{array}$ \\
\hline $\begin{array}{l}\text { Subjective } \\
\text { Norm (SN) }\end{array}$ & $\begin{array}{l}\text { A person's point of view of the } \\
\text { degree to which significant people } \\
\text { favour or are not in favour of the } \\
\text { objective behaviour }\end{array}$ & $\begin{array}{l}\text { TAM2,TRA } \\
\text { /TPB }\end{array}$ \\
\hline $\begin{array}{l}\text { Perceived } \\
\text { Behavioural } \\
\text { Control (PBC) } \\
\text { A being's point of view regarding } \\
\text { make the objective the behaviour of } \\
\text { elements that hinder or ease the }\end{array}$ & TPB \\
\hline
\end{tabular}

\begin{tabular}{|l|l|l|}
\hline & $\begin{array}{l}\text { control that a person has above } \\
\text { performing the behaviour }\end{array}$ & \\
\hline $\begin{array}{l}\text { Effort } \\
\text { Expectancy }\end{array}$ & (Refer PEOU) & UTAUT \\
\hline $\begin{array}{l}\text { Performance } \\
\text { Expectancy }\end{array}$ & (Refer PU) & UTAUT \\
\hline $\begin{array}{l}\text { Social } \\
\text { Influence }\end{array}$ & (Refer SN) & UTAUT \\
\hline $\begin{array}{l}\text { Facilitating } \\
\text { Conditions }\end{array}$ & (Refer PBC) & UTAUT \\
\hline $\begin{array}{l}\text { Behavioural } \\
\text { beliefs, } \\
\text { normative } \\
\text { believes and } \\
\text { control beliefs }\end{array}$ & $\begin{array}{l}\text { A person's point of view regarding } \\
\text { particular positive or negative } \\
\text { results of applying objective } \\
\text { behaviour, particular groups or } \\
\text { individuals who promote or depress } \\
\text { the behaviour and particular factors } \\
\text { or situations simplify behaviour or } \\
\text { make it more complex }\end{array}$ & \\
\hline
\end{tabular}

\subsection{Summary of TAM and Modified versions}

Technology Acceptance Model has been modified and the table below lists the summary of TAM and modified versions together with their aims.

Table 2: Summary of TAM and modified versions aims

\begin{tabular}{|l|l|l|}
\hline $\begin{array}{l}\text { TAM and } \\
\text { modified } \\
\text { versions }\end{array}$ & Model Aim & Source \\
\hline TAM & $\begin{array}{l}\text { TAM was created to understand the } \\
\text { natural sequence joining external } \\
\text { variables to its user acceptance and } \\
\text { natural utilization in an } \\
\text { establishment. TAM helps in } \\
\text { comprehending the background of } \\
\text { perceived ease of use. }\end{array}$ & \\
\hline TAM2 & $\begin{array}{l}\text { TAM2 intends to comprehend } \\
\text { perceived usefulness in order to } \\
\text { create working place involvements } \\
\text { that would increase user acceptance } \\
\text { of new framework. }\end{array}$ & \\
\hline UTAUT & $\begin{array}{l}\text { UTAUT shapes a unified model as a } \\
\text { suitable instrument for managers } \\
\text { requiring to measure the probability } \\
\text { of success for modern technology } \\
\text { outlines. }\end{array}$ & \\
\hline TAM3 & $\begin{array}{l}\text { TAM3 offers a combined model } \\
\text { with significance assigned on } \\
\text { perceived usefulness and perceived } \\
\text { ease of use so that it can address how } \\
\text { managers and people who make } \\
\text { decisions can make informed } \\
\text { decisions regarding interventions }\end{array}$ & \\
\hline
\end{tabular}

\section{TAM criticisms and limitations}

TAM has been cited by numerous researchers due to its simplicity without taking into consideration, an actual application in their researches. In this section, some of the TAM criticisms and limitations are presented considering, utilization of the model technology-related studies in various disciplines.

\subsection{TAM criticisms}

TAM has been broadly criticized, regardless of how it is being frequently used, leading the founders to try to re-explain it 
numerously. TAM criticisms as a "theory" incorporate contentious heuristic value, restricted descriptive and foretelling capability, criticism triviality and short of any practical value [31]. TAM changed researchers' attention by moving it away from other significant research matters and it has caused the impression of progression in accumulating knowledge[31]. Moreover, various researchers have independently tried to extend TAM so that it can adapt to the continually changing information technology environments which resulted in a state of theoretical havoc and uncertainty [31].

Generally, TAM is based on a being's utilization of a computer, with an abstract idea of PU and disregarding essential social methods of Information Systems (IS) development and application, with no question that "where many technologies are actually best and social after-effects of using Information Systems (IS)" [31]. The system of PU and PEOU fail to notice other issues, for example, cost and structural imperatives that push users to adopt a new innovation [32].

According to [33] both TAM and TAM2 take responsibility for at most $40 \%$ of a technological framework's utilization. Some researchers gone through the limitations of TAM implementation under organisation setting into details, and indicated that better predictive capability can be reached even with the easy, simply applicable model when exact first screening methods are implemented [34].

Studies conducted by [35-37] found that PEOU is unlikely to become a determining factor of ATT and intention to use. Moreover, [34] reported the same results when researching on the adoption of Blockchain technology.

The study carried out by [38] revealed that PEOU has no impact on the adoption of multimedia online innovations for Malaysian small and medium-sized enterprises (SMEs). Similar findings were outlined by Hong Kong when evaluating small and medium-size enterprises (SMEs) [34].

\subsection{TAM limitations}

Several conditions must be taken into account so that a theoretical framework can be applied and researchers must be aware of the numerous limitations that exist. To better comprehend the factors that encourage improved utilization of information technology (IT), it is compulsory to have a broad theoretical and application knowledge of structures and frameworks through which IT utilization is investigated [39]. One of the restrictions of TAM relates to the variable that refer to the behaviour of clients, which is necessarily assessed over subjective measures like behavioural intention and interpersonal influence [39]. However, social influence as the subjective norm refers to when an individual is influenced by "word of mouth" from a fellow worker [39].

The second limitation of TAM is that underlines of behaviour is unable to be quantified reliably in an observed research, owing to various multiple subjective elements, for instance, values and norms of societies, individual features and personality attributes $[40,41]$. Consequently, a relative, friend argument that could influence technology use through demanding social influence is extremely fabricated $[40,41]$. Even though it might be correct in theory or for individual utilization of innovation, the concept might not be credible or precise in a working environment.

\section{Conclusion}

In the research area, many models and frameworks were proposed by researchers to explore the user acceptance behaviour on information technology and information systems. In the 1980s TAM was created, given that employees were not utilizing Information Technologies (ITs) made accessible to them. Numerous researchers in the discipline of technology acceptance, improved theories and frameworks to evaluate the utilization of recent innovations and these frameworks introduced factors that can influence user acceptance. This led TAM theory to go through numerous modifications. Writers and researchers have criticized the TAM model in terms of its variables. This study aims to determine and understand the usage and modifications of Technology Acceptance Model (TAM) for IT acceptance.

\section{Acknowledgement}

This review paper has been prepared by William Ratjeana Malatji under the supervision of Dr Van Eck and Prof Zuva and sustained by the Department of ICT at the Vaal University of Technology Johannesburg (Vanderbijlpark) in South Africa.

\section{References}

[1] H. Taherdoost, S. Sahibuddin, N. Jalaliyoon, "Smart Card Technology: Awareness and Satisfaction " Journal of Computing, 4(6), 128-132, 2012.

[2] H. Taherdoost, N. Jalaliyoon, M. Namayandeh, A. Forghani, M. Zamani, "Adoption Framework Expansion based on the Computer Ethics' Related Research Models and Ethical Scenarios Analysis," International Conference on Economics, Business and Management, 2(5), 219-223, 2010.

[3] H. Taherdoost, S. Sahibuddin, "How Security Issues Can Influence on Usafe of Electronic Service," Advanced in Information Science and Computer Engineering, 310-316, 2015.

[4] H. Taherdoost, G. Hamta, G. Ahoora, R. Club, A. Hamta, C. Tablokar, "Importance of Technology Acceptance Assessment for Successful Implementation and Development of New Technologies," Global Journal of Engineering Sciences, 1(3), 2019.

[5] H. Taherdoost, M. Masrom, "An Examination of Smart Card Technology Acceptance Using Adoption Model," ITI 2009 31st Conf. on Information Technology Interfaces, 329-334, 2009.

[6] A. Dillon, M. Morris, "User Acceptance of Information Technology: Theories and Models," Annual Review of Information Science and Technology 31(4), 3-32, 1996.

[7] H. Taherdoost, S. Sahibuddin, N. Jalaliyoon, "Smart Card Security," Technology and Adoption International Journal of Security, 5(2), 2011

[8] V. Venkatesh, F.D. Davis, "A theoretical extension of technology acceptance model: four longitudinal field studies," Management Science, 46(2), 186-204, 2000.

[9] V. Venkatesh, M. G. Morris, G.B. Davis, F.D. Davis, "User acceptance of information technology: Toward unified view. ," MIS Quaterly, 27(3), 425478, 2003.

[10] V. Venkatesh, H. Bala, "Technology acceptance model 3 and research agenda on interventions," Decision Sciences, 39(2), 273-315, 2008.

[11] H. Taherdoost, "A Review paper of Technology Acceptance and Adoption Models and Theories," Procedia Manufacturing, 22(1), 960-967, 2018.

[12] I. Ajzen, M. Fishbein, "Understanding attitude and predicting social behaviour.," Engelwood Cliffs. NJ: Prentice- Hall, 1980.

[13] F. D. Davis, "Perceived usefulness, perceived ease of use and user acceptance of information technology," MIS Quaterly, 13(1), 319-39, 1989.

[14] R. J. Holden, B.A. Karsh, "theoretical model of health information technology usage behaviour with implications for patient safety," Behav Inf Technolo, 28(1), 21-38, 2009.

[15] M. Fishbein, I. Ajzen, "Belief, attitude, intention, and behavior: An introduction to theory and research," Reading, MA: Addision-Wesley, 1975.

[16] R. P. Bagozzi, F.D. Davis, P.R. Warshaw, "Development and test of a theory of technological learning and usage," Human Relations, 45(7), 660-686, 1992. 
[17] P. Legris, J. Ingham, P. Collerette, "Why do people use information technology? A critical review of the technology acceptance model," Information \& Management, 40(3), 191-204, 2003.

[18] M. J. Sanchez-Franco, "WebCT-The quasimoderating effect of perceived affective quality on an extending Technology Acceptance Model," Computers \& Education, 54(1), 37-46, 2010, doi.org/10.1016/j.compedu.2009.07.005.

[19] B. Kim, " An empirical investigation of mobile data service continuance: Incorporating the theory of planned behavior into the expectationconfirmation model.," Expert Systems with Applications, 37(10), 7033-7039, 2010, doi.org/10.1016/j.eswa.2010.03.015.

[20] F. D. Davis, R.P. Bagozzi, P.R. Warshaw, " User acceptance of computer technology: A comparison of two theorical models. ," Management Science, 35(8), 982-1003, 1989, doi.org/10.1287/mnsc.35.8.982

[21] S. Liao, J.C. Hong, M.H. Wen, Y.C. Pan, Y.N. Wu, "Applying Technology Acceptance Model (TAM) to explore Users' Behavioral Intention to Adopt a Performance Assessment System for E-book Production " EURASIA Journal of Mathematics, 14(10), 2018, doi.org/10.29333/ejmste/9357.

[22] S. Taylor, P. Todd, "Assessing IT usage: a test of competing models," Inform Syst Res, 6(1), 1995.

[23] M. J. Scherer, "Living in the state of stucK, ", Fourth Edition ed. Cambridge MA: Brookline Books, 2005.

[24] N. Fathema, K. Sutton, "Factors influencing faculty members' Learning Management Systems adoption behavior: An analysis using the Technology Acceptance Model," International Journal of Trends in Economics Management \& Technology, 2(1), 20-28, 2013.

[25] N. Fathema, D. Shannon, M. Ross, "Expanding the Technology Acceptance Model (TAM) to examine faculty use of Learning Management Systems (LMS)," Journal of Online Learning and Teaching, 11(2), 210-233, 2015.

[26] B. P. Lowry, J. Gaskin, N.W. Twyman, T.L. Roberts, Bryan, "Taking fun and games seriously: Proposing the hedonicmotivation system adoption model (HMSAM)," Journal of the Association for Information Systems, 14(11), 617671, 2013.

[27] H. Nadri, B. Rahimi, N.A. Loft, S. Mahnaz, A. Garavand, S. Hadi, "Factors Affecting Acceptance of Hospital Information Systems Based on Etended Technology Acceptance Model. A case Study in Three Paraclinical Departments," Applied Clinical Informatics, 9(2), 238-247, 2018.

[28] J. Wu, " Developing an explorative model for SaaS adoption," Expert Systems with Applications, 38(1), 15057-15064, 2011.

[29] C. López-Nicolás, F.J. Molina-Castillo, H., Bouwman, "An assessment of advanced mobile services acceptance: Contributions from TAM and diffusion theory models," Information \& Management, 5(1), 2008.

[30] V. Venkatesh, F.D. Davis, " A model of the antecendents of perceived ease of use: Development and test," Decision Sciences, 27(3), 451-481, 1989.

[31] I. Benbasat, H. Barki, "Quo vadis, TAM?," Journal of the Association for Information Systems, 8(4),211, 2007.

[32] B. Lunceford, "Reconsidering Technology Adoption and Resistance: Observations of a Semi-Luddite," Eplorations in Media Ecology, 8(1), 29-47, 2009.

[33] Legris, "Assessing Tam Model," Journal of Computing, 191, 2003.

[34] J. Li, "Blockchain technology adoption: Examining the Fundamental Drivers," in Proceedings of the 2nd International Conference on Management Science and Industrial Engineering, 253-260, 2020.

[35] P. J. Hu, P. K. Chau, O.R. Sheng, "Examining the tehnoogy acceptance model using physician acceptance of telemedicine technology," Journal of Management Information Systems, 16(2), 91-112, 1999.

[36] J. Wu, S. Wang, "What drives mobile commerce?: An empirical evaluation of the revised technology acceptance model," Information \& Management, vol. 42(5), 719-729, 2005.

[37] T. P. Pikkarainen, K.H. Karjaluoto, "Consumer acceptance of online banking: An extension of the Technology Acceptance Model," Internet ResearchElectronic Networking Applications and Policy, 14(3), 224-235, 2004.

[38] D. J. Okafor, M. Nico, B.B. Azman, "The influence of perceived ease of use and perceived usefulness on the intention to use suggested online advertising workflow," Canadian Journal of Science ang Technology, 6(14), 2016.

[39] L. M. Maruping, H. Bala, V. Venkatesh, S.A. Brown, "Going beyond intention: Intergrating behavioral intergration into thr unified theory of acceptance and use of technology," Journal of the Association for Information Science and Technology, 68(3), 2016.

[40] M. C. Ang, T. Ramayah, H. Amin, "A theory of planned behavior perspective on hiring Malaysians with disabilities. Equality, Diversity and Inclusion," An International Journal, 34(3), 186-200, 2015.

[41] Y. Shan, K.W. King,"The effects of interpersonal tie strength and subjective norms on consumers' brand-related eWOM referral intentions," Journal of Interactive Advertising, 15(1), 16-27, 2015. 